\title{
Two New Members of Streptothricin Class Antibiotics from Streptomyces qinlingensis sp. nov
}

\author{
Zhiqin Ji, Mingan Wang, Jiwen Zhang, Shaopeng Wei, Wenjun Wu
}

Received: September 12, 2007 / Accepted: November 27, 2007

(C) Japan Antibiotics Research Association

\begin{abstract}
Four streptothricin-group antibiotics (1 4) were isolated from the fermentation broth of Streptomyces qinlingensis sp. nov. Along with the known antibiotics streptothricins F (1) and D (3), two new members of this class $(\mathbf{2}, \mathbf{4})$ were identified as 12-carbamoyl derivatives of $\mathbf{1}$ and 3 , respectively, mainly by analysis of the IR, HR-MS and NMR spectral data. The antibacterial activities of $\mathbf{1} \sim \mathbf{4}$ against Escherichia coli (MICs 3.1, 25.0, 3.1 and $12.5 \mu \mathrm{g} / \mathrm{ml}$ ), Bacillus subtilis (MICs 6.3, 25.0, 3.1 and $50 \mu \mathrm{g} / \mathrm{ml}$ ), Staphylococcus aureus (MICs 12.5, >100.0, $6.3,>100.0 \mu \mathrm{g} / \mathrm{ml}$ ), Bacillus cereus (MICs 25.0, 50.0, 25.0 and $50.0 \mu \mathrm{g} / \mathrm{ml}$ ) and Pseudomonas aeruginosa (MICs 50.0, $>100.0,50.0,>100.0 \mu \mathrm{g} / \mathrm{ml}$ ) were assayed by micro-broth dilution. The results based on MIC data indicated that 2 and 4 exhibited significantly less potent antibacterial activities when compared to that of $\mathbf{1}$ and $\mathbf{3}$.
\end{abstract}

Keywords Streptomyces qinlingensis, streptothricin, structural elucidation

\section{Introduction}

Streptothricins are a group of $\mathrm{N}$-glycoside antibiotics. The first member of this group antibiotics, streptothricin F (1), was isolated by Waksman and Woodruff from Streptomyces lavendulae in 1942 [1], van Tamelen proposed its structural formula until 1961 [2]. Since then, the probable structures of the other six members of streptothricins (A, B, C, D, E, and $\mathrm{X}$ ) were also reported $[3,4]$. The molecular structures of all these compounds were finally confirmed by a total synthesis of $\mathbf{1}$ in 1982, and the location of the carbamate moiety was reassigned from $\mathrm{C}-12$ to $\mathrm{C}-10[5,6]$. All streptothricins consist of carbamoylated D-gulosamine to which the $\beta$-lysine homopolymer ( $1 \sim 7$ residues) and the amide form of the unusual amino acid streptolidine (streptolidine lactam) are attached (Fig. 1). Also $\beta$ - $N$-acetyl derivatives of streptothricins E and D (3) were found from Streptomyces nojiriensis [7]. Achievements in the study of streptothricin antibiotics were reviewed in 1983 [8].

Streptothricins are broad-spectrum antibiotics, which exhibit the potent activity against wide range of bacteria as well as some pathogenic fungi [1]. Because of their inherent toxicity, none of them has been used clinically [9], but these antibiotics have potential value to exploit as some agricultural fungicides. Zhongshengmycin, which consists of streptothrins $\mathrm{A} \sim \mathrm{F}$, has been registered as

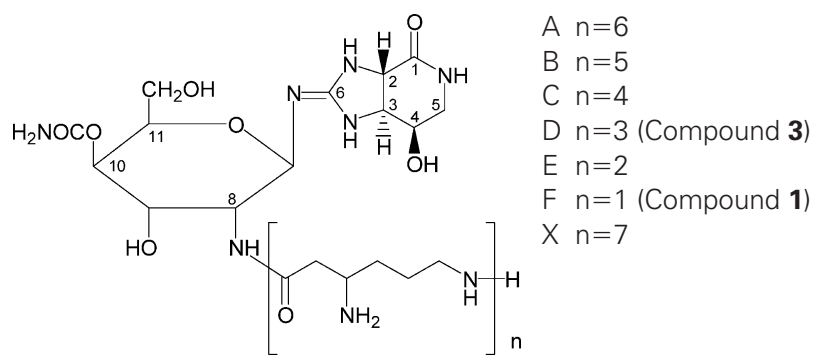

Fig. 1 Structures of streptothricin-group antibiotics $A \sim F$ and $X$.
W. J. Wu (Corresponding author), Z. Q. Ji, J. W. Zhang, S. P. Wei: Institute of Pesticide Science, Northwest Agricultural \& Forestry University, Yangling, Shaanxi 712100, P.R.China,

E-mail: wenjun_wu@263.net.
M. A. Wang: Department of Applied Chemistry, China Agricultural University, Beijing 100094, P.R.China. 
agricultural antibioctics to control some bacterial diseases in China [10]. Recently, a new streptothricin family antibiotic producing Streptomyces spp. SNUS 8810-111 was isolated from a Korea soil sample, and produced 3 and $N$-methylstreptothricin D $[11,12]$. Studies were conducted to address the formation and timing of incorporation of the arginine-derived base streptolidine in the biosynthesis of 1 [13]. Although many streptothricinresistance genes have been identified, only one resistance mechanism has been identified. A novel streptothricinresistance gene ( $\mathrm{SttH})$ was successfully isolated from $S$. albulus [14]. An SttH gene-knockout mutant to better understand the true biologicol role of $\mathrm{SttH}$ in S. albulus and to clarify whether or not $S$. albulus possesses different streptothricin-resistance gene(s) was also constructed [15].

In the process of screening new antibiotics, we found four streptothricin antibiotics (1 4) from the fermentation broth of $S$. qinlingensis sp. nov, a new Streptomyces strain isolated from a soil sample collected in Qinling mountain, Shannxi province, China. In the present paper, the isolation, structure elucidation, and preliminary bioassay of two new streptothricin-group antibiotics from $S$. qinlingensis are presented.

\section{Materials and Methods}

\section{Microorganism}

The producing strain $S$. qinlingensis sp. nov was isolated from a soil sample collected in Qinling mountain, Shannxi province, China, and identified by testing its morphology, physiology, biochemistry, and 16S rRNA gene sequence as a new strain. The voucher specimen of this actinomycete was deposited at the China General Microbiological Culture Collection Center as CGMCC1381, and the 16S rDNA sequence was registered in Genebank (Accession No: AM167521 in National Center for Biological Information).

\section{Fermentation}

The spores of $S$. qinlingensis sp. nov. grown on Gause's No. 1 agar was used to inoculate into a $250-\mathrm{ml}$ flask containing $100 \mathrm{ml}$ of a sterile seed medium consisting of glucose $0.8 \%$, soluble starch $0.8 \%$, beef extract $0.6 \%$, peptone $1.0 \%$, and $\mathrm{NaCl} 0.5 \%, \mathrm{pH} 7.2$. The flask was shaken on a shaker at $210 \mathrm{rpm}$ for 24 hours at $28^{\circ} \mathrm{C}$.

Ten milliliters of the seed culture was transferred to 250 $\mathrm{ml}$ flasks containing of $100 \mathrm{ml}$ of a sterile producing medium consisting of glucose $3.0 \%$, millet steep liquor $1.0 \%$, peptone $1.5 \%, \mathrm{NaCl} 0.5 \%$, and $\mathrm{CaCO}_{3} 0.5 \%, \mathrm{pH} 7.2$. Fermentation was carried out at $210 \mathrm{rpm}$ for 96 hours at $28^{\circ} \mathrm{C}$ on a rotary shaker.

\section{Isolation and Purification}

Ten liters of harvest fermentation broth were adjusted to $\mathrm{pH}$ 3.5 with oxalic acid and stirred for 30 minutes. The acidic broth was filtered and adjusted to $\mathrm{pH} \mathrm{8.0,} \mathrm{and} \mathrm{it} \mathrm{was} \mathrm{passed}$ through a column of HD-2 $\left(\mathrm{Na}^{+}, 2\right.$ liters). Active principle adsorbed on the column was eluted with $0.5 \mathrm{~N} \mathrm{HCl}$ (8.0 liters). The eluent was adjusted to $\mathrm{pH} 7.0$ and concentrated in vacuo to a small volume (about $300 \mathrm{ml}$ ). The concentrated solution was diluted with $\mathrm{MeOH}$ (3.0 liters) to precipitate $\mathrm{NaCl}$. $\mathrm{MeOH}$ was removed on a rotary evaporator, and the aqueous solution was applied on a column of CM-Sephadex C-25 (0.5 liters, $\left.\mathrm{Na}^{+}\right)$. The column was eluted with a linear gradient of water and $1.0 \mathrm{M} \mathrm{NaCl}$ solution (1.0 liter each). The eluents were collected in 50-ml fractions with two acitive peaks observed at fractions $61 \sim 68$ and 90 96, which were combined to two fractions. Two active fractions were desalted further by charomatography on active carbon columns and concentrated under reduced pressure to a small volume (about $10 \mathrm{ml}$ ), respectively. The concentrated fractions were further separated by ion-pair RP-HPLC on a column of Hypersil ODS-BP (column size $10 \times 250 \mathrm{~mm}$, particle size $10 \mu \mathrm{m}$, flow rate $3.5 \mathrm{ml} /$ minute, monitored by $\mathrm{RI}$ detector), fractions $61 \sim 68$ was eluted with $5.0 \% \mathrm{MeOH}$ containing 2.0\% TFA, and fraction 90 96 was eluted with $8.0 \% \mathrm{MeOH}$ containing $6.0 \%$ TFA. Four main fractions were collected according to the peaks in the HPLC profiles, each fraction was lyophilized, redissolved in water and passed through a column packed with 717 resin $\left(\mathrm{Cl}^{-}\right.$, $50 \mathrm{ml}$ ) to exchange TFA for chloride. Finally, the samples were lyophilized and stored as solids. $1(152 \mathrm{mg})$ and $\mathbf{2}$ (28 mg) were obtained from fraction $61 \sim 68,3(160 \mathrm{mg})$ and $4(80 \mathrm{mg})$ were from fraction $90 \sim 96$, respectively.

\section{General Methods}

Melting points were measured on an $\mathrm{X} 4$ apparatus and uncorrected. IR spectra were recorded on a Nicolet FT-IR 750 spectrometer ( $\mathrm{KBr}$ plate, $v_{\max }$ in $\mathrm{cm}^{-1}$ ); all ${ }^{1} \mathrm{H}-,{ }^{13} \mathrm{C}$ NMR, DEPT, COSY, HSQC and HMBC spectra were taken on a Bruker Avance $500 \mathrm{MHz}\left(500 \mathrm{MHz}\right.$ for ${ }^{1} \mathrm{H}$ and $125 \mathrm{MHz}$ for ${ }^{13} \mathrm{C}$, respectively) spectrometer in $\mathrm{D}_{2} \mathrm{O}$ with TMS as an internal standard. The ESI-MS and HRESI-MS spectra were obtained on a Finnigan LCQ LC/MS ${ }^{\mathrm{n}}$, and a Bruker APEX II mass spectrometer using glycerol as matrix. Optical rotation was measured in $\mathrm{MeOH}$ solution on a Perkin-Elmer 341 Polarimeter. Ion-exchange resins HD-2 and 717 were purchased from Shanghai Huazhen Sci. \& Tch. Co., Ltd.

\section{Antibacterial Assay}

MICs of 1 4 against Bacillus subtilis, Staphylococcus 
aureus, Escherichia coli, Bacillus cereus, and Pseudomonas aeruginosa were tested by the micro-broth dilution method [16]. The inoculum was prepared by suspending several colonies from an overnight culture of tested bacteria from $5.0 \%$ sheep blood agar media in Mueller-Hinton broth, and adjusting to a 0.5 McFarland standard (approximately $1.5 \times 10^{8}$ colony-forming units per $\mathrm{ml}$ ). A further dilution of $1: 200$ was made by placing $0.25 \mathrm{ml}$ of the adjusted suspension into $49.75 \mathrm{ml}$ of Mueller-Hinton broth. Stock solutions of tested compounds and streptomycin (positive control) in sterile water were prepared at the concentration of $1000 \mu \mathrm{g} / \mathrm{ml}$ and used immediately or stored in working samples at $-20^{\circ} \mathrm{C}$ until used. Two-fold serial dilutions of the tested compounds were prepared in Mueller-Hinton broth. All antimicrobial solutions were prepared in large volumes $(50 \mathrm{ml}) ; 0.1 \mathrm{ml}$ samples of the antibiotic solutions and $0.1 \mathrm{ml}$ inoculated suspension of the test microorganism were delivered to wells of a 96-well plate. The final concentration of inoculum in each well was $3.7 \times 10^{5}$ colony-forming units per $\mathrm{ml}$. MIC endpoints were read after 18 hours of incubation at $35^{\circ} \mathrm{C}$, and were defined as the lowest concentration of antibiotics that resulted in no bacterial growth as indicated by the ODs at $650 \mathrm{~nm}$. The blank control tube only contained organisms. Three replications were used for each sample.

\section{Results and Discussion}

\section{Physico-chemical Properties of 1 4}

1: white amorphous powder, m.p. $220 \sim 222^{\circ} \mathrm{C}$ (dec.), $[\alpha]_{\mathrm{D}}^{25}$ $-45^{\circ}$ (c 0.1, MeOH). IR (KBr), $v_{\max } \mathrm{cm}^{-1}: 3271,3052$,

Table $1{ }^{1} \mathrm{H}-\mathrm{NMR}$ data for streptothricin antibiotics $(\mathbf{1} \sim \mathbf{4})$ in $\mathrm{D}_{2} \mathrm{O}$

\begin{tabular}{|c|c|c|c|c|c|c|c|c|}
\hline \multirow{2}{*}{$\begin{array}{c}\text { Position } \\
n\end{array}$} & \multicolumn{2}{|c|}{1 (Streptothricin F) } & \multicolumn{2}{|c|}{2 (12-Carbamoylstreptothricin F) } & \multicolumn{2}{|c|}{3 (Streptothricin D) } & \multicolumn{2}{|c|}{4 (12-Carbamoylstreptothricin D) } \\
\hline & $\delta$ & $J(H z)$ & $\delta$ & $J(\mathrm{~Hz})$ & $\delta$ & $J(\mathrm{~Hz})$ & $\delta$ & $J(\mathrm{~Hz})$ \\
\hline 2 & 4.64 (d) & 14 & 4.64 (d) & 14 & $4.63(d)$ & 15 & $4.63(d)$ & 15 \\
\hline 3 & 4.10 (d) & 14 & $4.10(d)$ & 14 & $4.09(\mathrm{~m})$ & - & $4.09(\mathrm{~m})$ & - \\
\hline 4 & $4.74(\mathrm{~m})$ & - & $4.75(\mathrm{~m})$ & - & $4.73(\mathrm{~m})$ & - & $4.74(\mathrm{~m})$ & - \\
\hline 5 & $3.83(d d)$ & 6,15 & $3.84(d d)$ & 6,15 & $3.81(d d)$ & 6,15 & $3.81(d d)$ & 5,15 \\
\hline 5 & $3.42(d)$ & 15 & $3.43(d)$ & 15 & $3.42(d)$ & 15 & $3.42(d)$ & 15 \\
\hline 7 & 5.11 (d) & 10 & 5.07 (d) & 10 & $5.10(d)$ & 10 & 5.05 (d) & 10 \\
\hline 8 & $4.28(d d)$ & 3,10 & $4.35(d d)$ & 3,8 & $4.26(d d)$ & 3,10 & $4.32(\mathrm{~m})$ & - \\
\hline 9 & $4.18(t)$ & 3 & $4.11(t)$ & 3.5 & $4.16(t)$ & 3.5 & $4.08(t)$ & 3.5 \\
\hline 10 & $4.79(\mathrm{~m})$ & - & 3.90 (d) & 3.5 & $4.79(\mathrm{~m})$ & - & 3.89 (d) & 3.5 \\
\hline 11 & $4.35(t)$ & 6 & $4.35(\mathrm{t})$ & 6 & $4.34(\mathrm{t})$ & 6 & $4.34(\mathrm{~m})$ & - \\
\hline 12 & 3.75 (d) & 6 & $4.26(\mathrm{~m})$ & - & 3.73 (d) & 6 & $4.26(\mathrm{~m})$ & - \\
\hline 12 & 3.75 (d) & 6 & $4.26(\mathrm{~m})$ & - & $3.73(d)$ & 6 & $4.26(\mathrm{~m})$ & - \\
\hline 15 & $2.82(d d)$ & 4,16 & $2.83(d d)$ & 5,17 & $2.76(d d)$ & 5,16 & $2.76(d d)$ & 5,16 \\
\hline 15 & $2.70(\mathrm{dd})$ & 4,16 & $2.71(\mathrm{dd})$ & 8,17 & $2.68(d d)$ & 8,17 & $2.68(d d)$ & 8,17 \\
\hline 16 & $3.71(\mathrm{~m})$ & - & $3.71(\mathrm{~m})$ & - & $3.66(\mathrm{~m})$ & - & 3.65 (m) & - \\
\hline 17 & $1.81(\mathrm{~m})$ & - & $1.81(\mathrm{~m})$ & - & $1.72(\mathrm{~m})$ & - & 1.71 (m) & - \\
\hline 18 & $1.81(\mathrm{~m})$ & - & $1.81(\mathrm{~m})$ & - & $1.65(\mathrm{~m})$ & - & 1.64 (m) & - \\
\hline 19 & 3.07 (m) & - & 3.07 (m) & - & $3.25(\mathrm{t})$ & 7 & $3.24(\mathrm{~m})$ & - \\
\hline 21 & & & & & $2.73(d d)$ & 5,16 & $2.72(\mathrm{dd})$ & 5,16 \\
\hline 21 & & & & & $2.62(\mathrm{dd})$ & 8,17 & $2.61(\mathrm{dd})$ & 8,17 \\
\hline 22 & & & & & $3.66(\mathrm{~m})$ & - & 3.66 (m) & - \\
\hline 23 & & & & & $1.72(\mathrm{~m})$ & - & $1.71(\mathrm{~m})$ & - \\
\hline 24 & & & & & $1.65(\mathrm{~m})$ & - & $1.64(\mathrm{~m})$ & - \\
\hline 25 & & & & & $3.22(\mathrm{t})$ & 7 & $3.24(\mathrm{~m})$ & - \\
\hline 27 & & & & & $2.70(\mathrm{dd})$ & 5,16 & $2.69(\mathrm{dd})$ & 5,16 \\
\hline 27 & & & & & $2.60(\mathrm{dd})$ & 8,17 & $2.59(\mathrm{dd})$ & 8,17 \\
\hline 28 & & & & & $3.66(\mathrm{~m})$ & - & 3.65 (m) & - \\
\hline 29 & & & & & $1.81(\mathrm{~m})$ & - & $1.78(\mathrm{~m})$ & - \\
\hline 30 & & & & & $1.81(\mathrm{~m})$ & - & $1.78(\mathrm{~m})$ & - \\
\hline 31 & & & & & $3.06(t)$ & 6 & 3.05 (m) & - \\
\hline
\end{tabular}


2955, 1708, 1653, 1552, 1493, 1394, 1354, 1302, 1189, 1134, 1078, 949, 914, $851 \mathrm{~cm}^{-1}$; ${ }^{1} \mathrm{H}-$ and ${ }^{13} \mathrm{C}-\mathrm{NMR}$ : see Tables 1 and 2; ESI-MS $(\mathrm{m} / \mathrm{z}): 503[\mathrm{M}+\mathrm{H}]^{+}, 252$ $[\mathrm{M}+2 \mathrm{H}]^{2+}$; HR-ESI-MS $(\mathrm{m} / \mathrm{z}): 503.2566[\mathrm{M}+\mathrm{H}]^{+}$, Calcd. for $\mathrm{C}_{19} \mathrm{H}_{35} \mathrm{~N}_{8} \mathrm{O}_{8}, 503.2572$.

2: white amorphous powder, m.p. $184 \sim 186^{\circ} \mathrm{C}$ (dec), $[\alpha]_{\mathrm{D}}^{25}-29^{\circ}(c \quad 0.1, \mathrm{MeOH})$. IR $v_{\max } \mathrm{cm}^{-1}: 3332,2924$, $1707,1652,1611,1558,1481,1391,1312,1280,1078$, 957, 925, $888 \mathrm{~cm}^{-1}$. ${ }^{1} \mathrm{H}-$ and ${ }^{13} \mathrm{C}-\mathrm{NMR}$ : see Tables 1 and 2 . ESI-MS $(m / z): 503[\mathrm{M}+\mathrm{H}]^{+}, 252[\mathrm{M}+2 \mathrm{H}]^{2+}$; HR-ESI-MS $(\mathrm{m} / \mathrm{z}): 503.2569[\mathrm{M}+\mathrm{H}]^{+}$, Calcd. for $\mathrm{C}_{19} \mathrm{H}_{35} \mathrm{~N}_{8} \mathrm{O}_{8}$, 503.2572.

3: white amorphous powder, m.p. $120 \sim 122^{\circ} \mathrm{C}$ (dec), $[\alpha]_{\mathrm{D}}^{25}-3.5^{\circ}$ (c 0.1, MeOH). IR (KBr), $v_{\max } \mathrm{cm}^{-1}: 3382$, 3274, 3081, 2936, 1718, 1651, 1555, 1448, 1388, 1309, $1258,1188,1129,1071,974,953,926,849 \mathrm{~cm}^{-1} ;{ }^{1} \mathrm{H}-$ and
${ }^{13} \mathrm{C}$-NMR: see Tables 1 and 2; ESI-MS $(\mathrm{m} / \mathrm{z}): 759$ $[\mathrm{M}+\mathrm{H}]^{+}, 380[\mathrm{M}+2 \mathrm{H}]^{2+} ;$ HR-ESI-MS $(\mathrm{m} / \mathrm{z}): 759.4473$ $[\mathrm{M}+\mathrm{H}]^{+}$, Calcd. for $\mathrm{C}_{31} \mathrm{H}_{59} \mathrm{~N}_{12} \mathrm{O}_{10}, 759.4477$.

4: white amorphous powder, m.p. $116 \sim 118^{\circ} \mathrm{C}$ (dec), $[\alpha]_{\mathrm{D}}^{25}-6.5^{\circ}(c 0.1, \mathrm{MeOH})$. IR $v_{\max } \mathrm{cm}^{-1}: 3383,3067$, 2930, 1718, 1652, 1558, 1491, 1390, 1309, 1253, 1069, 951, $849 \mathrm{~cm}^{-1}$; ${ }^{1} \mathrm{H}-$ and ${ }^{13} \mathrm{C}-\mathrm{NMR}$ : see Tables 1 and 2; ESIMS $(m / z): 759[\mathrm{M}+\mathrm{H}]^{+}, 380[\mathrm{M}+2 \mathrm{H}]^{2+}$; HR-ESI-MS $(\mathrm{m} / \mathrm{z}): 759.4478[\mathrm{M}+\mathrm{H}]^{+}$, Calcd. for $\mathrm{C}_{31} \mathrm{H}_{59} \mathrm{~N}_{12} \mathrm{O}_{10}$, 759.4477 .

\section{Structure Elucidation}

The IR spectra of $\mathbf{1} \sim \mathbf{4}$ showed the characteristic absorption bands at $1652 \sim 1653$ and $1558 \sim 1560 \mathrm{~cm}^{-1}$ which suggested that they are all peptides. The molecular formula of $\mathbf{1}$ and $\mathbf{2}$ were determined to be $\mathrm{C}_{19} \mathrm{H}_{34} \mathrm{~N}_{8} \mathrm{O}_{8}, \mathbf{3}$ and $\mathbf{4}$ were

Table $2{ }^{13} \mathrm{C}-N M R$ data for $\mathbf{1} \sim \mathbf{4}$ in $\mathrm{D}_{2} \mathrm{O}$

\begin{tabular}{|c|c|c|c|c|}
\hline Position & 1 & 2 & 3 & 4 \\
\hline 1 & 172.5 & 172.4 & 172.5 & 172.4 \\
\hline 2 & 56.9 & 56.9 & 57.0 & 56.9 \\
\hline 3 & 63.4 & 63.4 & 63.4 & 63.4 \\
\hline 4 & 63.4 & 63.4 & 63.4 & 63.4 \\
\hline 5 & 51.8 & 51.8 & 51.8 & 51.9 \\
\hline 6 & 165.3 & 164.9 & 165.3 & 164.9 \\
\hline 7 & 81.3 & 81.5 & 81.4 & 81.6 \\
\hline 8 & 51.4 & 51.8 & 51.4 & 51.9 \\
\hline 9 & 69.0 & 70.4 & 69.1 & 70.4 \\
\hline 10 & 72.6 & 71.6 & 72.6 & 71.7 \\
\hline 11 & 76.1 & 75.0 & 76.1 & 75.0 \\
\hline 12 & 62.9 & 66.5 & 62.9 & 66.5 \\
\hline 13 & 160.4 & 161.5 & 160.5 & 161.6 \\
\hline 14 & 174.6 & 174.6 & 174.8 & 174.7 \\
\hline 15 & 38.8 & 38.8 & 39.0 & 39.1 \\
\hline 16 & 50.8 & 50.8 & 51.1 & 51.0 \\
\hline 17 & 31.6 & 31.6 & 32.1 & 32.1 \\
\hline 18 & 25.5 & 25.5 & 26.9 & 26.9 \\
\hline 19 & 41.5 & 41.5 & 41.4 & 41.4 \\
\hline 20 & & & 174.4 & 174.4 \\
\hline 21 & & & 39.2 & 39.2 \\
\hline 22 & & & 51.1 & 51.0 \\
\hline 23 & & & 32.1 & 32.1 \\
\hline 24 & & & 26.9 & 26.9 \\
\hline 25 & & & 41.4 & 41.5 \\
\hline 26 & & & 174.2 & 174.2 \\
\hline 27 & & & 39.3 & 39.4 \\
\hline 28 & & & 51.3 & 51.3 \\
\hline 29 & & & 31.7 & 31.7 \\
\hline 30 & & & 25.5 & 25.2 \\
\hline 31 & & & 41.5 & 41.5 \\
\hline
\end{tabular}




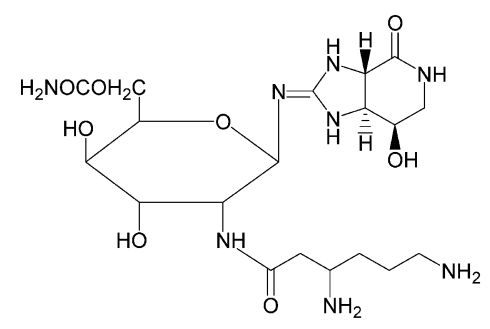

2 (12-Carbamoylstreptothricin F)

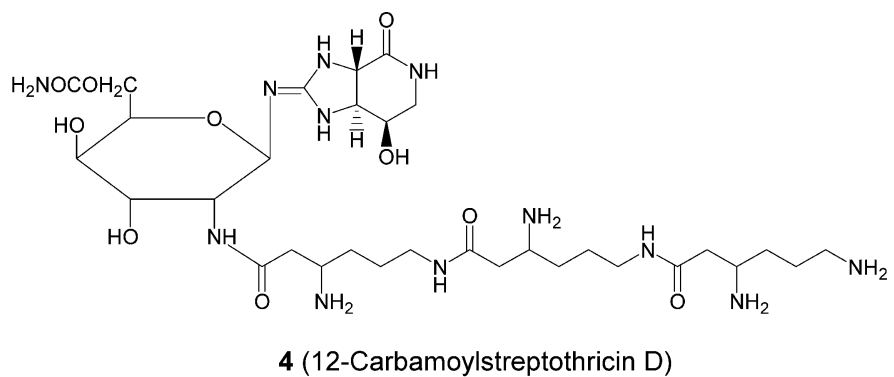

Fig. 2 Structures of two novel streptothricin antibiotics (2 and $\mathbf{4}$ ).

Table 3 Antibacterial in vitro activity of $\mathbf{1} \sim \mathbf{4}$ by micro-broth dilution

\begin{tabular}{|c|c|c|c|c|c|}
\hline \multirow{2}{*}{ Compounds } & \multicolumn{5}{|c|}{$\mathrm{MIC}(\mu \mathrm{g} / \mathrm{ml})$} \\
\hline & $\begin{array}{l}\text { Bacillus subtilis } \\
\text { (No. 1.0088) }\end{array}$ & $\begin{array}{c}\text { Staphylococcus aureus } \\
\text { (No. 1.0089) }\end{array}$ & $\begin{array}{c}\text { Escherichia coli } \\
\text { (No. 1.1636) }\end{array}$ & $\begin{array}{l}\text { Bacillus cereus } \\
\text { (No. 1.1846) }\end{array}$ & $\begin{array}{c}\text { Pseudomonas aeruginosa } \\
\text { (No. 1.2031) }\end{array}$ \\
\hline 1 (Streptothricin F) & 6.3 & 12.5 & 3.1 & 25.0 & 50.0 \\
\hline 2 & 25.0 & $>100.0$ & 25.0 & 50.0 & $>100.0$ \\
\hline 3 (Streptothricin D) & 3.1 & 6.3 & 3.1 & 25.0 & 50.0 \\
\hline 4 & 50.0 & $>100.0$ & 12.5 & 50.0 & $>100.0$ \\
\hline Streptomycin & 3.1 & 50.0 & 32.0 & 6.3 & 50.0 \\
\hline
\end{tabular}

determined to be $\mathrm{C}_{31} \mathrm{H}_{58} \mathrm{~N}_{12} \mathrm{O}_{10}$, on the basis of ${ }^{13} \mathrm{C}-\mathrm{NMR}$ and HR-ESI-MS. Based on the spectroscopic analysis, and comparison the ${ }^{1} \mathrm{H}$ - and ${ }^{13} \mathrm{C}$-NMR data with that reported in reference [17, 18], $\mathbf{1}$ and $\mathbf{3}$ were identified as streptothricin $\mathrm{F}$ and $\mathrm{D}$, respectively. Comparison the ${ }^{1} \mathrm{H}-$ and ${ }^{13} \mathrm{C}$-NMR data of $\mathbf{2}$ and $\mathbf{4}$ with that of $\mathbf{1}$ and $\mathbf{3}$, we found that the chemical shift of C-9 upfield $1.4 \delta, \mathrm{C}-10$ downfield $1.0 \delta, \mathrm{C}-11$ downfield $1.1 \delta$ and $\mathrm{C}-12$ upfield 3.6 $\delta$ in the ${ }^{13} \mathrm{C}-\mathrm{NMR}$ spectra, and the chemical shift of $\mathrm{H}-10$ upfield $0.9 \delta$ and $\mathrm{H}-12$ downfield $0.5 \delta$ in the ${ }^{1} \mathrm{H}-\mathrm{NMR}$ spectra. These differences maybe attribute to the variety of the substitution position of the carbamoyl group attached to the D-gulosamine in which the substitution position of carbamoyl was transfered from C-10 to C-12 [18]. This presumption was confirmed by the HMBC experiment. In the HMBC spectra of $\mathbf{1}$ and $\mathbf{3}$, the protons of $\mathrm{H}-9, \mathrm{H}-10$ and H-11 were correlated with the carbonyl of carbamoyl group. However, the carbonyl of carbamoyl group was correlated with the protons of $\mathrm{H}-10, \mathrm{H}-11$ and $\mathrm{H}-12$ in the HMBC spectra of $\mathbf{2}$ and $\mathbf{4}$. Thus the structures of $\mathbf{2}$ and $\mathbf{4}$ were finally elucidated as carbamoyl derivatives at C-12 of $\mathbf{1}$ and $\mathbf{3}$, respectively. To our best knowledge, there are only two similar structure compounds were reported before, which were found in the course of screening $N$-type calcium channel blockers in 1998, and they were finally identified as carbamoyl derivatives at C-12 of streptothricin C and B [19, 20], respectively. So 2 and $\mathbf{4}$ are two novel streptothricin antibiotics (Fig. 2).

\section{Biological Activity}

Antimicrobial activities of $\mathbf{1} \sim \mathbf{4}$ against $B$. subtilis, S. aureus, E. coli, B. cereus and P. aeruginosa were determined by the micro-broth dilution method, which were shown in Table 3. Comparing the MICs of $\mathbf{2}$ and $\mathbf{4}$ to those of $\mathbf{1}$ and $\mathbf{3}$, the antimicrobial activities of the former two compounds were significantly lower, indicating that the position of the carbamoyl group in the glucosamine moiety plays important role for the antimicrobial properties of this class of streptothricin antibiotic.

Acknowledgements This work was supported by the National Key Project for Basic Research of China (No. 2003CB114404) and the Hi-Tech Research and Development Project of China (No. 2002AA2455121). We wish to thank Xi'an Modern Chemistry Research Institute for NMR analysis.

\section{References}

1. Waksman SA, Woodruff HB. Streptothricin, a new selective bacteriostatic and bactericidal agent particularly against 
Gram-negative bacteria. Proc Soc Exptl Biol Med 49: 207-209 (1942)

2. van Tamelen EE, Dyer JR, Whaley HA, Carter HE, Whitfield GB. Constitution of the streptoline-streptothricin group of Streptomyces antibiotics. J Am Chem Soc 83: 4295-4296 (1961)

3. Khokhlov AS, Reshetov PD. Chromatography of streptothricins on carboxymethyl-cellulose. J Chromatogr 14: 495-496 (1964)

4. Taniyama H, Sawada J, Kitagawa T. Characterization of racemomycins. Chem Pharm Bull 19: 1627-1634 (1971)

5. Kusumoto S, Kambayashi Y, Imaoka S, Shima K, Shiba T. Total chemical structure of streptothricin. J Antibiot 35: 925-927 (1982)

6. Kusumoto S, Imaoka S, Kambayashi Y, Shiba T. Total synthesis of antibiotic streptothricin F. Tetrahedron Lett 23: 2961-2864 (1982)

7. Miyashiro S, Ando T, Hirayama K, Kida T, Shibai H, Murai A, Shiio T, Udaka S. New streptothricin-group antibiotics, AN-201 I and II. Screening, fermentation, isolation, structure and biological activity. J Antibiot 36: 1638-1643 (1983)

8. Khokhlov AS. Achievements in the study of streptothricin antibiotics. Antibiotiki 28: 613-622 (1983)

9. Shoichi K, Susumu I, Yoshikazu K, Kumiko Y, Tetsuo S. Synthesis of $N^{\mathrm{g}}$-streptolidyl gulosaminide-a new evidence for the proposed structure of antibiotic streptothricin. Chemistry Lett 10: 1317-1320 (1981)

10. Zhu CX. Zhongshengmycin, a new agro-antibiotics. Fine and Specialty Chemicals 10(16): 14-17 (2002)

11. Kim BT, Lee JY, Lee YY, Kim OY, Chu JH, Goo YM. N-Methylstreptothricin D-a new streptothricingroup antibiotic from a Streptomyces spp. J Antibiot 47: 1333-1336 (1994)

12. Goo YM, Kim OY, Joe YA, Lee YB, Ju J, Kim BT, Lee YY. A new streptothricin family antibiotic producing
Streptomyces spp. SNUS 8810-111: characterization of the producing organisms, fermentation, isolation, and structure elucidation of antibiotics. Arch Pharm Res 19: 153-159 (1996)

13. Jackson MD, Gould SJ, Zabriskie TM. Studies on the formation and incorporation of streptolidine in the biosynthesis of the peptidyl nucleoside antibiotic streptothricin F. J Org Chem 67: 2934-2941 (2002)

14. Hamano Y, Matsuura N, Kitamura M, Takagi H. A novel enzyme conferring streptothricin resistance alters the toxicity of streptothricin D from broad-spectrum to bacteriaspecific. J Biol Chem 281: 16842-16848 (2006)

15. Hamano $\mathrm{Y}$, Maruyama C, Kimoto $\mathrm{H}$. Construction of a knockout mutant of the streptothricin-resistance gene in Streptomyces albulus by electroporation. Actinomycetologica 20: 35-41 (2006)

16. Martha MT, David FW, Melvin IM. Antimicrobial susceptibility testing of Streptococcus pneumoniae by micro-broth dilution. Antimicrob Agents Chemother 18: 579-581 (1980)

17. Toshihiko A, Shigeyoshi M, Kazuo H, Takao K, Hiroshiro S, Asao M, Shigezo U. New streptothricin-group antibiotics, AN-201 I, II, and III, II. Chemical structures. J Antibiot 40: 1140-1145 (1987)

18. Yoshiyuki K, Kazuo Y, Shoshiro N. The structures of component A1 (=LL-AB664) and component A2 (=LLAC541), streptothricin-like antibiotics. J Antibiot 34: 921-922 (1981)

19. Marie H, Yoshinori I, Keiichi M, Hisao O, Ryuzo E, Takeshi K, Yoshiaki S, Takeshi K, Hideyuki H. Novel peptides, their manufacture with Streptomyces, and $N$-type calcium channel blockers. JP 08208690 (1996)

20. Marie H, Yoshinori I, Yoshiharu S, Takeshi K, Ryuzo E, Takao O, Hideyuki H, Takeshi K, Keiichi M. A-53930A and B, novel $N$-type $\mathrm{Ca}^{2+}$ channel blockers. J Antibiot 51: 607-617 (1998) 